\title{
Changes in Hydration of Lanthanide Ions on Binding to DNA in Aqueous Solution
}

\author{
Diana Costa,* Hugh D. Burrows, and M. da Graça Miguel \\ Departamento de Química, Universidade de Coimbra, 3004-535 Coimbra, Portugal
}

Received June 6, 2005. In Final Form: August 11, 2005

\begin{abstract}
The interaction of the trivalent lanthanides $\mathrm{Ce}(\mathrm{III}), \mathrm{Eu}(\mathrm{III})$, and $\mathrm{Tb}(\mathrm{III})$ with sodium deoxyribonucleic acid (DNA) in aqueous solution has been studied using their luminescence spectra and decays. Complexation with DNA is indicated by changes in luminescence intensity. In the system terbium(III)-DNA, changes in luminescence with $\mathrm{pH}$ are suggested to be due to the protonation of phosphate groups. The degree of hydration of $\mathrm{Tb}(\mathrm{III})$ on binding to DNA is followed by luminescence lifetime measurements in water and deuterium oxide solutions, and it is found that the lanthanide ion loses at least one hydration water on binding to long double stranded DNA at $\mathrm{pH} 4.7$ and $\mathrm{pH}$ 7. Rather different behavior is observed on binding to long or short single stranded DNA, where six water molecules are lost, independent of $\mathrm{pH}$. It is suggested that in this case the lanthanide probably binds to the bases of the DNA backbone. The DNA conformation seems to be an important factor in the binding. In addition, the isotopic effect on terbium luminescence lifetime may provide a useful method to distinguish between single and double stranded DNA. DSC results are consistent with cleavage of the double helix of DNA at $\mathrm{pH} 9$ in the presence of terbium.
\end{abstract}

\section{Introduction}

DNA is a negatively charged polyelectrolyte, and the binding of metal cations to it is of importance since this plays a crucial role in the biological activity of nucleotides and nucleic acids, changing their properties in ways that depend on the nature of the metal ion. ${ }^{1}$ Knowledge of the mechanisms responsible for the activity of these systems requires the study of metal ion-nucleic acid interactions. These can lead to DNA denaturation, compaction, aggregation, or precipitation. ${ }^{2,3}$ It has been shown that cations with a valence $\geq 3$ are generally required to induce the condensation of DNA in aqueous solution. Among the multivalent cations, spermidine(IV), ${ }^{4}$ spermine(III),${ }^{5}$ and the hexaamminecobalt complex, $\left[\mathrm{Co}\left(\mathrm{NH}_{3}\right)_{6}\right]^{3+6}$ have been shown to induce DNA condensation through studies involving light-scattering, sedimentation, electron microscopy, and various spectroscopic methods. ${ }^{7,8}$ Although electrostatic interactions are likely to be of major importance in the binding, other factors may also be involved, ${ }^{9-12}$ and many questions still remain unanswered on the driving force for this process.

Trivalent lanthanide ions have attractive, spectroscopic, and magnetic properties ${ }^{13}$ and have been used as probes

* To whom correspondence should be addressed. Fax: $+351-239$ 82 7703. E-mail: diana.costa@fkem1.lu.se.

(1) Stryer, L. Biochemistry; W. H. Freeman and Company: San Francisco, CA, 1994

(2) Bloomfield, V. A. Biopolymers 1997, 44, 269-282

(3) Duguid, J. A.; Bloomfield, V. A. Biophys. J. 1995, 69, 2623-2641.

(4) Gosule, L. C.; Schellman, J. A. Nature 1976, 259, 333-335.

(5) Gosule, L. C.; Schellman, J. A. J. Mol. Biol. 1978, 121, 311-333.

(6) Widom, J.; Baldwin, R. L. J. Mol. Biol. 1980, 144, 431-453.

(7) Bloomfield, V. A. Curr. Opin. Struct. Biol. 1996, 6, 334-341.

(8) Bloomfield, V. A.; Ma, C.; Arscott, P. G. In Macro-Ion Characterization: From Dilute Solutions to Complex Fluids; Schmitz, K. S., Ed.; American Chemical Society: Washington, DC, 1994; pp 195.

(9) Manning, G. S. Acc. Chem. Res. 1979, 12, 443-449.

(10) Lau, A. W. C.; Pincus, P. Phys. Rev. E 2002, 66, 041501.

(11) Schwinefus, J. J.; Bloomfield, V. A. Biopolymers 2000, 54, 572577.

(12) Wennerstrom, H. Curr. Opin. Colloid Interface Sci. 2004, 9, 163164.

(13) Bünzli, J.-C. G.; Choppin, G. R. Lanthanide Probes in Life, Chemical and Earth Sciences: Theory and Practice; Elsevier: Amsterdam, 1989. of the interactions of metal ions with DNA. Nucleic acids may be considered to be ambidentate ligands, with various potential binding sites, including nitrogen and oxygen donors on the bases, hydroxyl groups on the ribose sugar, and negatively charged oxygen atoms in the phosphate groups. As a consequence of the abundance of negatively charged oxygen donor groups, the DNA molecule readily interacts with $\mathrm{Ln}^{3+}$ ions and may be expected to occupy at least some of the inner-sphere coordination sites of the cations, contributing to the coordination process by completing chelate bridges. ${ }^{14}$ Interactions are expected to have pronounced effects on the spectral properties of these ions. The luminescence properties of $\mathrm{Tb}^{3+}, \mathrm{Eu}^{3+}$, and $\mathrm{Ce}^{3+}$ make them versatile in their applications to examination of biomolecular structures. ${ }^{15}$ The first two of these cations are of special interest due to the fact that their resonance energy levels overlap the triplet energy states of protein and nucleic acid aromatic residues leading to enhancement of their natural fluorescence by energy transfer when irradiated with ultraviolet light. ${ }^{16}$ Similar behavior has been observed on binding by other polyelectrolyte systems. ${ }^{17}$ Binding stoichiometries remain a problem in carrying out quantitative staining studies, but when $\mathrm{Tb}^{3+}$ or $\mathrm{Eu}^{3+}$ luminescence exhibits significant sensitivity to binding these may be estimated from luminescence titration measurements. ${ }^{18-21}$ These cations possess many similarities in their properties to calcium(II) and the isomorphous replacement of this cation by $\mathrm{Ln}^{3+}$ ions holds out the promise of exploiting the rich and variety spectroscopic properties of the lanthanide ions for obtaining information on the structure of $\mathrm{Ca}$ (II) in biological

(14) Marzilli, L. G. Prog. Inorg. Chem. 1977, 23, 255-378.

(15) Richardson, F. S. Chem. Rev. 1982, 82, 541-552.

(16) Yonushot, G.; Mushrush, G. W. Biochemistry 1975, 14, 16771681 .

(17) Tapia, M. J.; Burrows, H. D. Langmuir 2002, 18, 1872-1876.

(18) Barala, T. D.; Burchett, J.; Kizer, D. E. Biochemistry 1975, 14, 4887-4892.

(19) Furie, B. C.; Furie, B. J. Biol. Chem. 1975, 250, 601-608. 209.

.

(21) Snyder, A. P.; Sudnick, D. R.; Aekle, V. K.; Horrocks, W. DeW., Jr. Biochemistry 1981, 20, 3334-3339. 
systems. ${ }^{22,23}$ Also, their ability to substitute $\mathrm{Zn}(\mathrm{II})^{24,25}$ and $\mathrm{Mg}(\mathrm{II})$ at their binding sites makes lanthanide luminescence a useful tool to study interaction between DNA and these ions. ${ }^{26-29}$ In addition, polyelectrolyte/lanthanide ion systems are amenable to modeling by Monte Carlo and other techniques, which can help provide a more detailed understanding of the binding behavior. ${ }^{30}$

The luminescence of the lanthanide ions arises from $f$ $\rightarrow$ f electron transitions and this can give information on both the coordination environment ${ }^{31,32}$ and degree of hydration of these ions. ${ }^{23,33}$ There is increasing interest in long-lived luminescent probes ${ }^{34-36}$ and lanthanide ions would appear to be good candidates for this, particularly as their emission is not quenched by oxygen. The luminescence of $\operatorname{Ln}$ (III) ions is extremely weak when compared to organic fluorophores, principally because of the low oscillator strength $\left(\sim 10^{-6}\right)$ of their absorption bands. ${ }^{37,38}$ This is because lanthanide $\mathrm{f} \rightarrow \mathrm{f}$ transitions are generally forbidden by both spin and Laporte selection rules. ${ }^{39,40}$ In contrast, with cerium(III), the lowest energy electronic band in absorption corresponds to the allowed $4 \mathrm{f} \rightarrow 5 \mathrm{~d}$ transition. Although this results in a much broader band than with the other trivalent lanthanides, it does mean that the transition has a reasonable molar absorption coefficient. ${ }^{41,42}$ In certain cases, the inherent weakness of $\operatorname{Ln}($ III) ion luminescence may be overcome by an energy transfer process, and interest in energy transfer in these systems has increased dramatically in the past few years ${ }^{43-47}$ due to applications in luminescent assays in physics, chemistry, and biochemistry. For this phenomena, both dipole-dipole (Förster $)^{48}$ and exchange (Dexter) ${ }^{49}$ mechanisms have been suggested for energy transfer

(22) Reuben, J. In Handbook on the Physics and Chemistry of Rare Earths; Gschneider, K. A., Eyring, L., Eds.; North-Holland: Amsterdam 1979; Vol. 4, p 515

(23) Horrocks, W. DeW., Jr.; Sudnick, D. R. Acc. Chem. Res. 1981, $14,384-392$

(24) Lehninger, A. L. Physiol. Rev. 1950, 30, 393-429.

(25) Lindskog, S. Struct. Bonding 1970, 8, 153-196.

(26) Topal, M. D.; Fresco, J. R. Biochemistry 1980, 19, 5531-537.

(27) Ringer, D. P.; Burchett, S.; Kiser, D. E. Biochemistry 1978, 17, $5531-5537$.

(28) Ringer, D. P.; Howell, B. A.; Kiser, D. E. Anal. Biochem. 1980, $103,337-342$.

(29) Nieboer, E. Struct. Bonding (Berlin) 1975, 22, 1-47.

(30) Sarraguça, J. M. G.; Skepö, M.; Pais, A. A. C. C.; Linse, P. J. Chem. Phys. 2003, 119, 12621-12628.

(31) Horrocks, W. DeW., Jr.; Albin, M. Prog. Inorg. Chem. 1984, 31, $1-104$.

(32) Chopin, G. R.; Wang, Z. M. Inorg. Chem. 1997, 36, 249-252.

(33) Shannon, R. D. Acta Crystallogr. 1976, Sect. A, A32, 751-767.

(34) Almgren, M. Adv. Colloid Interface Sci. 1992, 41, 9-32.

(35) Miguel, M. G.; Burrows, H. D.; Formosinho, S. J.; Lindman, B.

J. Mol. Struct. 2001, 563, 89-98.

(36) Burrows, H. D.; Miguel, M. G. Adv. Colloid Interface Sci. 2001, $89,485-496$.

(37) Stein, G.; Würzberg, E. J. Chem. Phys. 1975, 62, 208-213.

(38) Horrocks, W. DeW., Jr.; Sudnick, D. R. J. Am. Chem. Soc. 1979, 101, 334-340.

(39) Carnall, W. T.; Fields, P. R.; Rajnak, K. J. Chem. Phys. 1968 ,

49, 4447-4449.

(40) Halladay, H. N.; Petersheim, M. Biochemistry 1988, 27, 21202126.

(41) Blasse, G.; Schipper, W.; Hamelink, J. Inorg. Chim. Acta 1991, $189,77-80$.

(42) Okada, K.; Kaizu, Y.; Kobayashi, H.; Tanaka, K.; Marumo, F. Mol. Phys. 1985, 54, 1293-1306.

(43) Parker, D.; Williams, J. A. G. J. Chem. Soc., Dalton Trans. 1996 3613-3628

(44) Wolbers, M. P. O.; van Veggel, F. C. J. M.; Peters, F. G. A.; van Beelen, E. S. E.; Hofstraat, J. W.; Geurts, F. A. J.; Reinhoudt, D. N. Chem. Eur. J. 1998, 4, 772-780.

(45) Choppin, G. R.; Peterman, D. R. Coord. Chem. Rev. 1998, 174, $283-299$.

(46) Parker, D. Coord. Chem. Rev. 2000, 205, 109-130.

(47) Lis, S.; Elbanowski, M.; Makowska, B.; Hnatejko, Z. J. Photo-

chem. Photobiol. AB 2002, 150, 233-247.

(48) Förster, T. Discuss. Faraday Soc. 1959, 27, 7-17.

(49) Dexter, D. L. J. Chem. Phys. 1953, 21, 836-850. involving lanthanide ions. ${ }^{50,51}$ However, in the latter case, this requires relatively close contact and is favored by complexation $^{52}$ or binding of complexes of the ions to charged species, such as micelles, ${ }^{53}$ phospholipid or various vesicles, ${ }^{54}$ or other biologically relevant systems. ${ }^{55}$

Luminescence decay lifetimes of lanthanides provide a direct measure of the number of metal-coordinated water molecules. Replacement of $\mathrm{OH}$ oscillators by the OD ones causes the vibronic deexcitation pathway to become exceedingly inefficient, and the resultant isotope effect on luminescence lifetimes permits the determination of the number of water molecules in the first coordination sphere of metal ion, ${ }^{56-62}$ in addition to the changes in hydration on lanthanide ion binding.

We have carried out a detailed study of the association of trivalent lanthanide ions $\mathrm{Ce}^{3+}, \mathrm{Eu}^{3+}$, and $\mathrm{Tb}^{3+}$ with double stranded DNA (2000 base pairs) using their luminescence. We are aware that lanthanide ions catalyze the hydrolysis of nucleic acids. ${ }^{63}$ However, this effect is not important under our experimental conditions. To study the mechanisms of binding, the following well-defined DNA samples have been used: (1) long ds-DNA (2000 base pairs), long ss-DNA (heat-denatured 2000 bases), and short ss-DNA (580 and 831 base pair fragments). Particular emphasis is placed on the effect of binding on the cation hydration sphere.

\section{Materials and Methods}

Cerium (III), europium (III), and terbium (III) perchlorates from Aldrich were of the purest grade available and were used as received. Deoxyribonucleic acid sodium (DNA) from salmon testes (Sigma) was used as supplied. Its molecular weight is around 2000 base pairs (bp). Salmon DNA was thermally denatured to produce ss-DNA by heating at $90^{\circ} \mathrm{C}$ for $10 \mathrm{~min}$ and then cooling rapidly by injecting the sample into a beaker that is cooled by immersion into a mixture of cold ice and ethanol. ${ }^{64}$ The conformation of DNA in aqueous solution, that is whether the chains are single or double stranded, was verified by differential scanning calorimetry (DSC) measurements. Short DNA single stranded from salmon testes was purchased from Sigma. This DNA is precipitated in ethanol and sonicated to produce single stranded fragments which comigrate with the 580 and 831 base pair marked fragments. Solutions were prepared using Millipore-Q water. Deuterium oxide (99.9 at. \%) from Aldrich was used in preparing solutions for determining the number of water molecules in the phosphorescence decay measurements. The solution $\mathrm{pH}$ is modified from $\mathrm{pH} 4.7$ to $\mathrm{pH}$ 7 and 9 by the addition of small volumes of dilute $\mathrm{NaOH}$ solution.

The DNA concentration was measured by its absorbance at $260 \mathrm{~nm}, \epsilon_{260}=6600 \mathrm{M}^{-1} \mathrm{~cm}^{-1} . A_{260} / A_{280}$ ratio of DNA solutions was about 1.8-1.9 indicating the absence of protein contamina-

(50) Frey, S. T.; Horrocks, W. DeW., Jr. Inorg. Chem. 1991, 30, 10731079

(51) Dong, W.; Flint, C. D. J. Chem. Soc., Faraday Trans. 1992, 88, 2661-2665

(52) Neilson, J. D.; Shepherd, T. M. J. Chem. Soc., Faraday Trans 2 1976, $72,557-564$ 21

(1993, 93, 199-

(54) Sun, J.; Petersheim, M. Biochim. Biophys. Acta 1990, 1024, 159166

(55) Elbanowski, M.; Makowska, B. J. Photochem. Photobiol. A: Chem. 1996, $99,85-92$.

(56) Kropp, J. L.; Windsor, M. W. J. Phys. Chem. 1967, 71, 477-482. 2770

Kropp, J. L.; Windsor, M. W. J. Chem. Phys. 1963, 39, 2769

(58) Kropp, J. L.; Windsor, M. W. J. Chem. Phys. 1966, 45, 761.

(59) Heller, A. J. Am. Chem. Soc. 1966, 88, 2058-2059.

(60) Haas, Y.; Stein, G. J. Phys. Chem. 1971, 75, 3668-3677.

(61) Haas, Y.; Stein, G. J. Phys. Chem. 1971, 75, 3677-3681.

(62) Haas, Y.; Stein, G. J. Phys. Chem. 1972, 76, 1093-1104.

(63) Komiyama, M.; Takeda, N.; Shigekawa, H. Chem. Commun. $1999,77,1443-1445$.

(64) Krasna, A.-I. Biopolymers 1970, 9, 1029-1038. 


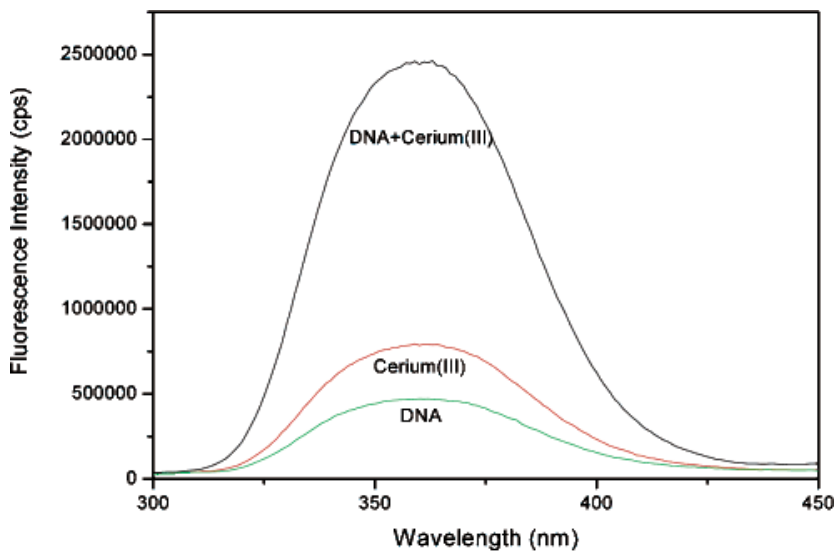

Figure 1. Emission spectra $\left(\lambda_{\mathrm{exc}}=280 \mathrm{~nm}\right)$ for long ds-DNA $\left(10^{-5} \mathrm{M}\right)$; cerium (III) $\left(\left[\mathrm{Ce}^{3+}\right]=10^{-5} \mathrm{M}\right)$ and cerium (III)-long ds-DNA system $\left(\left[\mathrm{Ce}^{3+}\right]=10^{-5} \mathrm{M},[\mathrm{DNA}]=10^{-5} \mathrm{M}\right)$. Temperature $25^{\circ} \mathrm{C}, \mathrm{pH}$ of the solutions: 4.7.

tion. ${ }^{65}$ Absorption spectral measurements were made in $1 \mathrm{~cm}$ quartz cuvettes on a Shimadzu UV-2100 spectrophotometer. For luminescence spectral measurements, a Spex Fluorolog 111 was used in $90^{\circ}$ configuration, with emission and excitation spectra recorded using appropriate excitation or emission wavelengths. In experiments with the system DNA-terbium(III) an appropriate filter was introduced in front of the emission monochromator to eliminate higher order bands. Terbium(III) luminescence lifetimes were measured using the Spex 1934D phosphorimeter accessory with the Fluorolog 3-22 instrument, and decays were analyzed by using the program Origin 6.0 (Microcal). A high sensitivity differential scanning calorimeter Microcal MC-2 (Microcal Inc. Northampton, MA) was used to perform the DSC measurements. This is equipped with thin twin total-fill cells of $1.18 \mathrm{~mL}$ for the reference and sample solutions. The solutions were degassed (Nueva II stirrer, Termolyne) before being transferred to the cells using a Hamilton syringe. The instrument measures the power required to keep the temperature of the sample and reference cells equal while the temperature is raised (upscan) or lowered (downscan) at a constant rate. Origin software (version 6.0) was used for data acquisition and analyses.

\section{Results and Discussion}

Luminescence Studies. Initial observations were made on the phase behavior of aqueous solutions of DNA in the presence of lanthanide ions. Upon addition of cerium(III), terbium(III), or europium(III) to an aqueous solution of DNA $\left(10^{-5} \mathrm{M}\right)$ at room temperature, formation of a precipitate was observed at lanthanide concentrations above $10^{-3} \mathrm{M}$. The concentration of lanthanide ions, on adding long ds-DNA, was then decreased until the concentration limit detected to avoid precipitation and clear isotropic solutions were observed.

Information on the system cerium(III)-long ds-DNA (pH 4.7) at a molecular level was obtained by studying the emission spectrum of an aqueous solution of cerium(III) perchlorate. In the presence of long ds-DNA $\left(10^{-5} \mathrm{M}\right)$, a marked increase in $\mathrm{Ce}$ (III) fluorescence intensity was observed, as shown in Figure 1. Emission spectra were also obtained for the system long ds-DNA-cerium(III) at different cerium concentrations keeping the DNA concentration constant. Small blue shifts in the emission maxima and a marked increase in fluorescence intensity were observed (Figure 2) due to a selective binding of the lanthanide to the DNA, probably with cerium lying close to the phosphate groups. As shown in Figure 2, the increase of $\mathrm{Ce}^{3+}$ emission intensity is linear up to about $5 \times 10^{-4}$ $\mathrm{M}$, but tends to a plateau at higher cerium concentration.

(65) Cantor, C. R.; Schimmel, P. R. Biophysical Chemistry; W. H. Freeman and Co.: San Francisco, CA, 1980; p 1371.

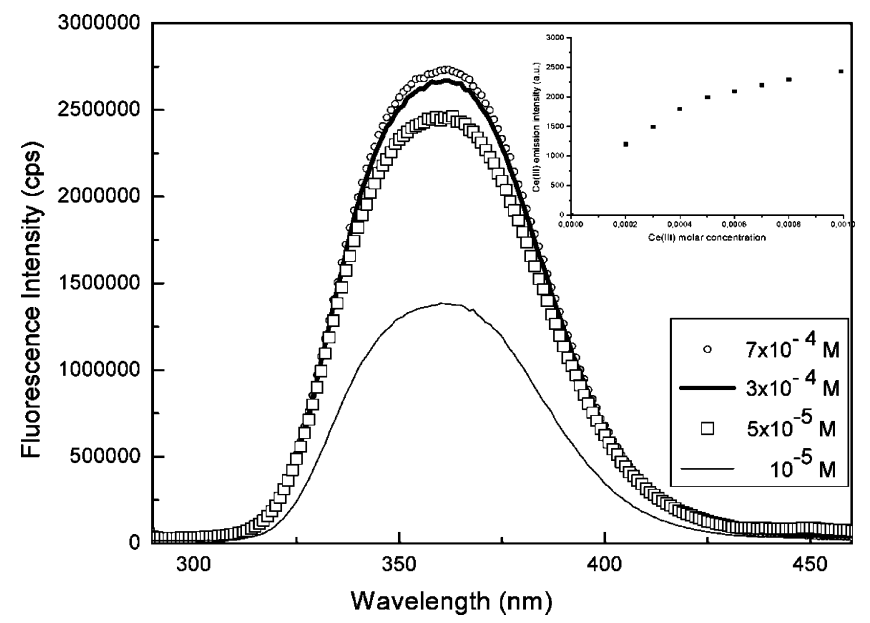

Figure 2. Emission spectra $\left(\lambda_{\text {exc }}=280 \mathrm{~nm}\right)$ for the complex Ce(III)-long ds-DNA with different cerium concentrations $\left(10^{-5}\right.$ $\mathrm{M}, 5 \times 10^{-5} \mathrm{M}, 3 \times 10^{-4} \mathrm{M}$, and $\left.7 \times 10^{-4} \mathrm{M}\right)$. DNA concentration is constant $\left([\mathrm{DNA}]=10^{-5} \mathrm{M}\right)$. Temperature $25^{\circ} \mathrm{C}, \mathrm{pH}$ of the solutions: 4.7 .

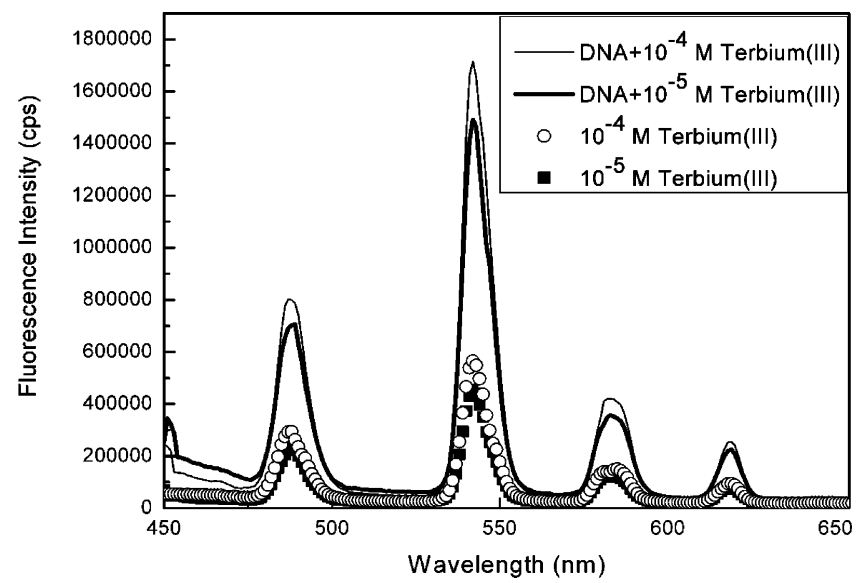

Figure 3. Emission spectra $\left(\lambda_{\mathrm{exc}}=280 \mathrm{~nm}\right)$ for $\mathrm{Tb}(\mathrm{III})$ at different concentrations $\left(10^{-5} \mathrm{M}\right.$ and $\left.10^{-4} \mathrm{M}\right)$ in the absence of long ds-DNA and for the complex Tb(III)-long ds-DNA at the same concentrations. Long ds-DNA concentration is constant $\left([\mathrm{DNA}]=10^{-5} \mathrm{M}\right)$. Temperature $25^{\circ} \mathrm{C}, \mathrm{pH} 4.7$.

This parallels to the onset of turbidity of the system and is most probably due to phase separation. Similar plateau was observed for europium(III), which has its main excitation and emission bands at 394 and $585 \mathrm{~nm},{ }^{66}$ for the same charge/base ratio.

Emission spectra were studied of aqueous solution of $\mathrm{Tb}$ (III) in the absence and presence of long ds-DNA (Figure 3). In the samples without DNA, the luminescence intensity of the emission bands increases, as expected, as a function of terbium ion concentration. In the presence of DNA, the most sensitive band is in the region 530-550 $\mathrm{nm}$; this increase in intensity is more significant than in the other bands. Such an increase in intensity has been attributed to energy transfer ${ }^{67}$ However, we believe this is not the only factor involved and that changes in hydration of the cation may also be responsible. These observations indicate that the DNA interaction with the lanthanide ion may be changing its local coordination sphere, and we believe that this process is probably accompanied by the substitution of water molecules in the coordination sphere of terbium ion by coordination with phosphate groups.

(66) Kayne, M. S.; Cohn, M. Biochemistry 1974, 13, 4159-4165.

(67) Fu, P. K.-L.; Turro, C. J. Am. Chem. Soc. 1999, 121, 1-7. 


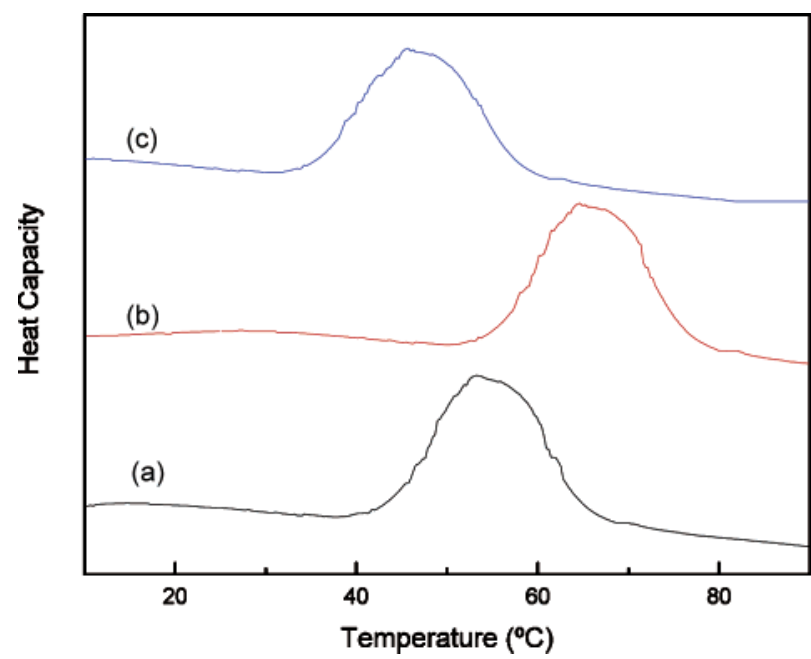

Figure 4. Differential scanning calorimetry traces for solutions of long ds-DNA $10^{-5} \mathrm{M}$ at different $\mathrm{pH}$ values: (a) $\mathrm{pH} 4.7$, (b) $\mathrm{pH} 7$, and (c) $\mathrm{pH} 9$.

From these luminescence studies, we have chosen terbium to give a deeper insight into the binding behavior of lanthanide ions and DNA.

Structure of DNA: Double Stranded versus Single Stranded. Information about the DNA structure in the presence of terbium at different $\mathrm{pH}$ values was obtained by differential scanning calorimetry (DSC). This is one of the most powerful methods to check if the DNA molecule is in its native state, double stranded, or denaturated state, single stranded, ${ }^{6-70}$ by studying the so-called melting point or melting temperature $\left(T_{\mathrm{m}}\right)$, which is defined as the temperature at which half of the helical structure is lost. Dilute, long ds-DNA solutions $\left(10^{-5} \mathrm{M}\right)$ were studied in the absence of terbium (III) for different values of $\mathrm{pH}$ ( $\mathrm{pH} 4.7,7$, and 9). As can be seen from Figure 4, the curves are identical in shape and a melting transition, indicating a double stranded conformation of DNA, is observed for all samples. However, as has previously been shown ${ }^{71,72}$ helix stability is affected by the $\mathrm{pH}$ of the solution, and this consequently also affects the temperature at which melting occurs. For DNA samples at $\mathrm{pH} 4.7$ this occurs at $53^{\circ} \mathrm{C}$; on increasing the $\mathrm{pH}$ to 7 the $\mathrm{ds}$-DNA molecules are stabilized to higher temperatures $\left(64^{\circ} \mathrm{C}\right)$, whereas at $\mathrm{pH} 9$ this decreases to $45^{\circ} \mathrm{C}$. Although the reason for this decrease is not clear, it may be associated with ionization of the phosphate groups.

We performed the same studies varying the $\mathrm{pH}$ for long ds-DNA samples in the presence of terbium ([Tb(III)] = $10^{-4} \mathrm{M}$, [DNA] $=10^{-5} \mathrm{M}$ ). In Figure 5, for $\mathrm{pH} 4.7$ and 7, a peak is observed corresponding to the DNA melting, indicating that even in the presence of the trivalent ion the DNA double-helix arrangement is maintained. However, the melting temperature at $\mathrm{pH} 7$ decreases in the presence of terbium to $50{ }^{\circ} \mathrm{C}$, whereas at $\mathrm{pH} 4.7$ the $T_{\mathrm{m}}$ was identical to that in the absence of $\mathrm{Tb}(\mathrm{III}), 53{ }^{\circ} \mathrm{C}$. A more dramatic change was observed for the DNA sample at $\mathrm{pH}$ 9. No transition was seen at $\mathrm{pH} 9$, suggesting that at this $\mathrm{pH}$ the DNA molecules have changed to the singlestranded conformation. Terbium is known to interact with

(68) Cao, W.; Lai, L. Biophys. Chem. 1999, 80, 217-226.

(69) Bastos, M.; Castro, V.; Mrevlishvili, G.; Teixeira, J. Biophys. J. 2004, 86, 3822-3826.

(70) Rosa, M.; Dias, R.; Miguel, M. G.; Lindman, B. Biomacromolecules 2005, 6, 2164-2171.

(71) Williams, M. C.; Wenner, J. R.; Rouzina, I.; Bloomfield, V. A. Biophys. J. 2001, 80, 874-881.

(72) Rouzina, I.; Bloomfield, V. A. Biophys. J. 2001, 80, 894-900.

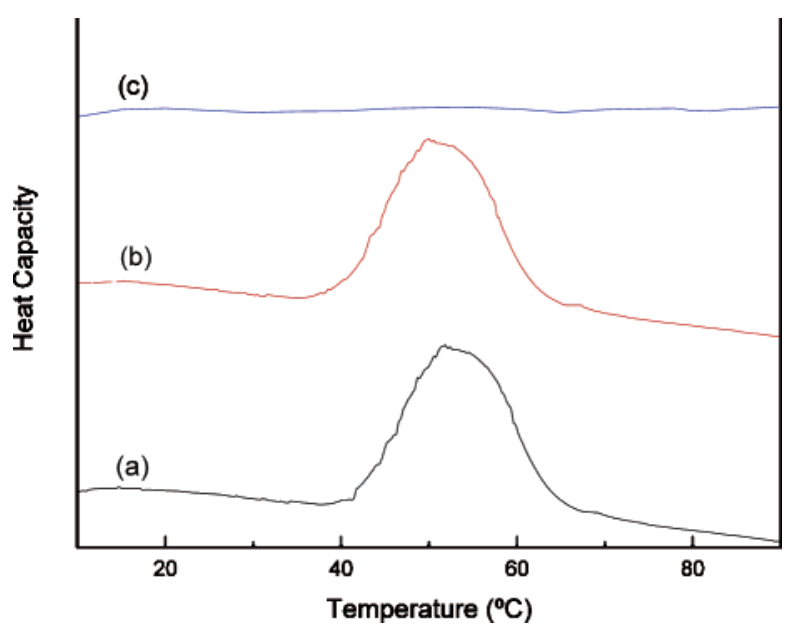

Figure 5. Differential scanning calorimetry traces for solutions of terbium-long ds-DNA ([Tb(III)] $=10^{-4} \mathrm{M}$, [DNA] $=10^{-5} \mathrm{M}$ ) at different $\mathrm{pH}$ values: (a) $\mathrm{pH} 4.7$, (b) $\mathrm{pH} 7$, and (c) $\mathrm{pH} 9$.

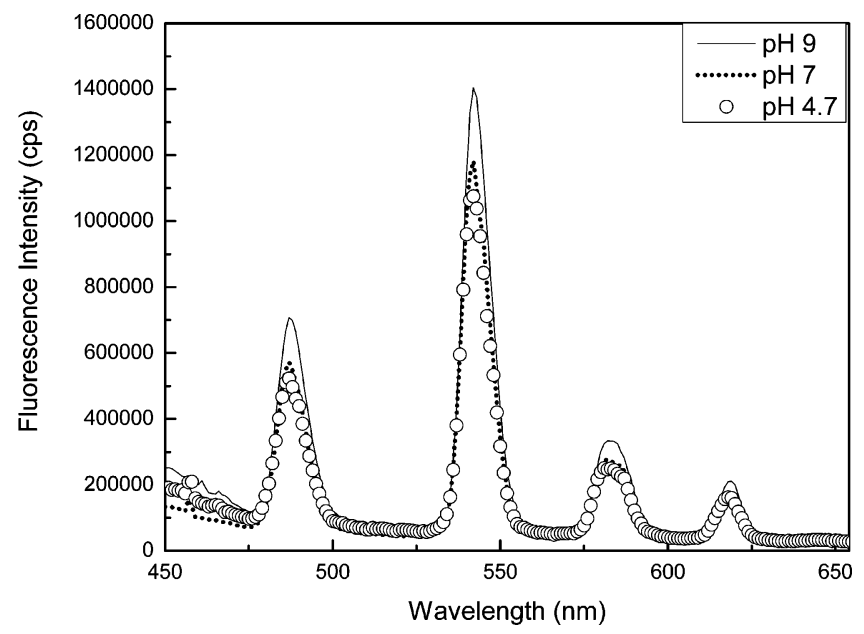

Figure 6. Emission spectra $\left(\lambda_{\text {exc }}=280\right)$ for the complex Tb(III)-long ds-DNA([Tb(III)] $=10^{-4} \mathrm{M}$, [DNA] $\left.=10^{-5} \mathrm{M}\right)$ with different $\mathrm{pH}$ values $(4.7,7$, and 9$)$. Temperature $25{ }^{\circ} \mathrm{C}$.

DNA by destabilizing the double helix through the breaking of hydrogen bonds, which leads to a lowering of the melting point $\left(T_{\mathrm{m}}\right){ }^{73,74}$ Once a base pair of a turn in a double helix is separated, terbium can bind directly to the bases. Single-stranded DNA molecules have the hydrophobic bases more exposed to the solution than dsDNA, which can lead to formation of more binding sites, along with strong electrostatic interactions. In the presence of $\mathrm{Tb}$ (III), renaturation of DNA was not observed on changing $\mathrm{pH}$ from 9 to 7 . This suggests that at $\mathrm{pH} 9$ terbium denatures DNA and binds single strands, probably by interacting irreversibly with the bases. Differences in the mechanisms of binding with $\mathrm{pH}$ will be shown later to lead to differences in the number of water molecules released.

Further information was obtained by studying the emission spectrum of aqueous solution of terbium (III) in the presence of long ds-DNA at different $\mathrm{pH}$ values $(4.7$, 7, and 9). The results are presented in Figure 6. Differences in the luminescence intensities were observed, with the highest intensity at $\mathrm{pH} 9$, in agreement with the different binding behavior due to the DNA being in a single-stranded conformation. In addition, there are differences in the

(73) Gross, D. S.; Simpkins, H. J. Biol. Chem. 1981, 256, 9593-9598.

(74) Rittich, B.; Španová, A.; Falk, M.; Beneš, M. J.; Hrubý, M. J. Chromatogr. B 2004, 800, 169-173. 
Table 1. Lifetime, $\tau$, and the Number of Coordinated Water Molecules, $n$, of $\mathrm{Tb}$ (III) in Water and $\mathrm{D}_{2} \mathrm{O}$ and in Long ds-DNA, Long ss-DNA, Short ss-DNA Aqueous and $\mathrm{D}_{2} \mathrm{O}$ Solutions

\begin{tabular}{llll}
\hline \multicolumn{1}{c}{ samples } & $\tau_{\mathrm{H}_{2} \mathrm{O}}$ & $\tau_{\mathrm{D}_{2} \mathrm{O}}$ & $n$ \\
\hline Tb pH 4.7 & 0.46 & 4.43 & $9.1 \pm 0.5$ \\
Tb-long ds-DNA pH 4.7 & 0.53 & 3.18 & $7.4 \pm 0.5$ \\
Tb-long ss-DNA pH 4.7 & 0.57 & 0.66 & $3.2 \pm 0.5$ \\
Tb-short ss-DNA pH 4.7 & 0.58 & 0.64 & $3.1 \pm 0.5$ \\
Tb pH 7 & 0.43 & 4.26 & $9.1 \pm 0.5$ \\
Tb-long ds-DNA pH 7 & 0.42 & 2.02 & $8.1 \pm 0.5$ \\
Tb-long ss-DNA pH 7 & 0.58 & 0.63 & $3.0 \pm 0.5$ \\
Tb-short ss-DNA pH 7 & 0.59 & 0.65 & $3.3 \pm 0.5$ \\
Tb pH 9 & 0.49 & 4.35 & $9.1 \pm 0.5$ \\
Tb-long ss-DNA pH 9 & 0.58 & 0.65 & $3.2 \pm 0.5$ \\
Tb-short ss-DNA pH 9 & 0.55 & 0.65 & $3.1 \pm 0.5$
\end{tabular}

degree of protonation of the phosphate groups, which are protonated at $\mathrm{pH} 4.7$, but not at $\mathrm{pH}$ 9. At physiological $\mathrm{pH}$ ( $\mathrm{pH} 7$ ), the phosphate groups of the backbone are also protonated, which may explain the very small difference in the luminescence bands at $\mathrm{pH} 4.7$ and 7. At pH 4.7 and 7 , we believe that terbium binding to DNA mainly involves the phosphate groups. However, the luminescence and DSC results for $\mathrm{pH} 9$ indicate another mechanism of binding, which probably also involves the bases of DNA molecule.

Hydration Studies via Lifetimes in $\mathrm{H}_{2} \mathrm{O}$ and $\mathrm{D}_{2} \mathrm{O}$ Solutions. Additional information on terbium-DNA interactions was obtained by studying the decay of the lanthanide ion luminescence. As indicated in the Introduction, the terbium lifetimes are quite sensitive to the detailed nature of the ligand environment, and the effect of deuteration on the $\mathrm{Tb}$ (III) luminescence decay in $\mathrm{H}_{2} \mathrm{O}$ and $\mathrm{D}_{2} \mathrm{O}$ solutions provides a valuable method for measuring the number of coordinated water molecules. ${ }^{23,38}$ Water $\left(\mathrm{H}_{2} \mathrm{O}\right)$ molecules (and $\mathrm{OH}^{-}$ions) are generally much more effective nonradiative relaxers of lanthanide excited states than are other ligands or ligand donor groups, whereas $\mathrm{D}_{2} \mathrm{O}$ molecules (and $\mathrm{OD}^{-}$ions) are not efficient. This difference in the excited lanthanide ions lifetimes in $\mathrm{H}_{2} \mathrm{O}$ versus $\mathrm{D}_{2} \mathrm{O}$ solutions can be exploited in determining the number of water molecules coordinated to $\mathrm{Tb}(\mathrm{III})$. The decay of $\mathrm{Tb}$ (III) luminescence was studied alone ([Tb$\left.(\mathrm{III})]=10^{-4} \mathrm{M}\right)$ and in the presence of DNA $([\mathrm{Tb}(\mathrm{III})]=$ $10^{-4} \mathrm{M}$, [DNA] $\left.=10^{-5} \mathrm{M}\right)$ in $\mathrm{H}_{2} \mathrm{O}$ and $\mathrm{D}_{2} \mathrm{O}$ solutions. Good exponential decays were observed. From these, the number of bound water molecules was determined (Table 1). The values for aqueous solution in the absence of DNA are in good agreement with literature data ${ }^{75}$ and are consistent with $\mathrm{Tb}$ (III) being coordinated to 9 water molecules for $\mathrm{pH}$ values 4.7, 7, and 9. However, in the presence of long ds-DNA, the number of bound water molecules appears to decrease to approximately 8 at $\mathrm{pH} 4.7$ and 7 and to approximately 3 water molecules at $\mathrm{pH} 9$. This loss of one or five water molecules is obviously related to the different way terbium binds to DNA at different $\mathrm{pH}$ values. On binding of lanthanide ions to poly(vinyl sulfonate), six water molecules are lost. ${ }^{17}$ Although it is dangerous to extrapolate to the behavior of other metal ions and polyelectrolytes, we believe that the entropy change caused by the dehydration of metal cations may be one of the important factors favoring their binding to polyelectrolytes. It has been suggested for lanthanide ion binding to polynucleotides that this involves mainly negatively charged phosphate groups. ${ }^{76}$ We think that this contact

(75) Horrocks, H. D.; Sudnick, D. R. J. Am. Chem. Soc. 1979, 101, $334-340$

(76) Izatt, R. M.; Christensen, J. J.; Rytting, J. H. Chem. Rev. 1971, $71,439-481$ is likely to replace one or more water molecules. At higher $\mathrm{pH}$ values, binding to other groups, such as guanine, may also occur.

As the results with $\mathrm{Tb}$ (III) show, $\mathrm{pH}$ is a parameter that must be taken into account in the binding. However, when we observe the results for long ss-DNA and short ss-DNA at $\mathrm{pH} 4.7,7$, and 9 the conformation of DNA helix seems to be a crucial factor in determining the number of water molecules which are replaced by phosphate groups. At any pH studied, six water molecules were lost by terbium on binding to ss-DNA. Two possible explanations exist for this, either it results from the greater flexibility, and hence enhanced binding capacity, of the DNA chain, or binding may involve the bases, such as guanine. Our data does not allow us to distinguish between these, but model studies using nucleotides are in progress to attempt to clarify this.

In addition to its value in indicating changes in hydration on binding to DNA, the isotopic effect on terbium luminescence lifetime may provide a useful method to distinguish between single and double stranded DNA. Steady state and time-resolved fluorescence of organic dyes has already been shown to be a valuable means of determining the single-to-double stranded DNA ratio in solution. ${ }^{77,78}$ Studies using long-lifetime lanthanide probes are likely to provide complementary information.

\section{Conclusion}

In conclusion, luminescence studies were used to study the interaction of long ds-DNA between the trivalent ions cerium (III), europium (III), and terbium (IIII). The spectra observed in aqueous solution in the presence and absence of long ds-DNA show significant differences which suggest complexation. With cerium and europium, this binding is evident from the dependence of emission intensity on concentration, where a plateau regime has been found. For the terbium (III)-long ds-DNA system, interesting dependence on $\mathrm{pH}$ was observed; this is related to the protonation or deprotonation of the phosphate groups and also to changes on the helical structure of DNA. At pH 4.7 and 7 , the helical double stranded structure was maintained, but at $\mathrm{pH} \mathrm{9,} \mathrm{this} \mathrm{structure} \mathrm{was} \mathrm{lost} \mathrm{and} \mathrm{single}$ stranded molecules of DNA are formed. Two possible mechanisms seem to be present. One involving negatively charged phosphate groups and another mainly involving the bases of ss-DNA nucleotides, such as guanine. The analysis of the $\mathrm{Tb}$ (III) lifetimes in $\mathrm{H}_{2} \mathrm{O}$ and $\mathrm{D}_{2} \mathrm{O}$ are made at different $\mathrm{pH}$. It was found that the lanthanide ion loses one water molecule on binding the long ds-DNA at $\mathrm{pH} 4.7$ and 7, and six water molecules at $\mathrm{pH} 9$. On binding long ss-DNA and short ss-DNA, terbium loses six water molecules at $\mathrm{pH} 4.7,7$, and 9. Similar behavior is observed with the short and long chain polymers.

Acknowledgment. We are grateful to POCTI(POCTI/ QUI/35415/2000, POCTI/QUI/39593/2001 and POCTI/ QUI/45344/2002), FCT (SFRH/BD/16736/2004), and FEDER for financial support.

\section{LA051493U}

(77) Cosa, G.; Focsaneanu, K.-S.; McLean, J. R. N.; McNamee, J. P.; Scaino, J. C. Photochem. Photobiol. 2001, 73, 585-599.

(78) Beach, L.; Schweitzer, C.; Scaiano, J. C. Org. Biomol. Chem. 2003, 1, 450-451. 